\title{
Protocol
}

\section{Methylated CpG Island Amplification and Microarray (MCAM) for High-Throughput Analysis of DNA Methylation}

\author{
Marcos R. H. Estécio ${ }^{1,3}$, Pearlly S. Yan², Tim H-M. Huang ${ }^{2}$, and Jean-Pierre J. Issa ${ }^{1}$ \\ ${ }^{1}$ Department of Leukemia, University of Texas M.D. Anderson Cancer Center, Houston, TX 77030, USA \\ ${ }^{2}$ Human Cancer Genetics Program, Ohio State University Comprehensive Cancer Center, Columbus, OH 43210, USA
}

\section{INTRODUCTION}

This protocol describes the use of methylated $\mathrm{CpG}$ island amplification (MCA) in combination with a microarray platform to analyze genome-wide DNA methylation in a high-throughput fashion. In this approach, termed MCAM, methylated CpG islands are selectively targeted using oligonucleotide adaptors after two rounds of digestion with a combination of methylation-sensitive and methylationinsensitive nucleases. They are then amplified using PCR. The resulting amplicons, representing the methylated fraction of the genome, are labeled with fluorochromes. Subsequently, a comparative hybridization of reference and test samples (typically normal and tumor DNA specimens) is done on a microarray platform.

\section{RELATED INFORMATION}

This protocol has been tested in cancer cell lines and primary tumors (Estécio et al. 2007). Validation experiments by bisulfite-PCR (considered to be the gold standard) of fifteen genes in three cancer lines and eleven primary colorectal carcinomas revealed sensitivity and specificity of $88 \%$ and $96 \%$, respectively. Additionally, MCAM could detect methylation differences of as little as $10 \%$ between tumor and normal adjacent paired colon samples.

\section{MATERIALS}

CAUTIONS AND RECIPES: Please see Appendices for appropriate handling of materials marked with $<!>$, and recipes for reagents marked with $<\mathbf{R}>$.

\section{Reagents}

Agarose gel (1.5\%)

Cot-1DNA (human; Invitrogen)

Cy3-dCTP and Cy5-dCTP (GE Healthcare)

$<$ !>DMSO (see note at Step 10)

dNTP mix $(25 \mathrm{mM})$

Ethanol (prechilled to $4^{\circ} \mathrm{C}$ for Step 23)

Genomic DNA 
Klenow fragment of DNA polymerase I

The best source for this exonuclease at 40 units/ $\mu \mathrm{L}$ is the Bioprime DNA Labeling System (Invitrogen).

$<$ R $>$ LowC dNTP mix (10X)

$<\mathrm{R}>$ MCA reaction buffer $(10 \mathrm{X})$

$<$ R $>$ MCAM wash solution 1

MCAM wash solution 2

$<\mathrm{R}>\mathrm{SSC}(20 \mathrm{X})$ is diluted 100 -fold in $\mathrm{H}_{2} \mathrm{O}$ to prepare this wash solution, which is $0.2 \mathrm{XSSC}$.

Oligonucleotide primers:

We have developed two different sets of primers (RMCA and RXMA) that differ in CG content and represent slightly different subsets of $\mathrm{CpC}$ islands. On average, the RMCA primers amplify smaller and more CG rich fragments than RXMA. Some probes work well using either condition, but others work better (or exclusively) using only one of the sets of primers. In our experience, the use of either set of primers for MCAM resulted in similar sensitivity and specificity. For this reason, one set of primers per experiment can be successfully used to reveal global patterns of methylation.

Octomers (random, 8N)

RMCA Primers (RMCA24 : 5'-CCACCGCCATCCGAGCCTTTCTGC-3'; RMCA12 : 5'CCGGGCAGAAAG-3')

RXMA Primers (RXMA24 : 5'-AGCACTCTCCAGCCTCTCACCGAC-3'; RXMA12 : 5'CCGGGTCGGTGA-3')

PCR Purification kit (QIAquick kit; Qiagen)

$<$ !>Phenol:chloroform (1.5:1 [v/v]; pH 9.0)

$<\mathrm{R}>$ Prehybridization solution for MCAM

$<$ R $>$ React2 buffer (10X)

Restriction enzymes: Smal and Xmal

SDS hybridization solution (2X; Genisphere)

Sodium acetate (3 M)

T4 DNA ligase and 10X ligase buffer

Taq DNA polymerase

$<\mathrm{R}>$ TE buffer $(\mathrm{pH} 8.0)$

\section{Equipment}

Beaker (large)

Centrifugal filter unit (e.g., Microcon YM-30; Millipore)

Centrifuge (benchtop)

Coverslips

Dishes (slide staining)

Electrophoresis equipment for $1.5 \%$ agarose gel

Hot plate

Hybridization chamber (e.g., HybChamber Mica, Genomic Solutions)

Ice

Incubator preset to $42^{\circ} \mathrm{C}$

Microarray slides

Microcentrifuge

PCR equipment

Rack (for slides)

Rocker platform

Scanner and software (e.g., Genepix 4000B scanner and GenepixPro 6.0 software; Axon Instruments)

Spectrophotometer

Tubes (1.7-mL microcentrifuge)

Vortexer

Water bath preset to $60^{\circ} \mathrm{C}$

Water baths or heat blocks preset to $16^{\circ} \mathrm{C}, 25^{\circ} \mathrm{C}, 37^{\circ} \mathrm{C}, 65^{\circ} \mathrm{C}, 95^{\circ} \mathrm{C}$, and $100^{\circ} \mathrm{C}$ 


\section{METHOD}

Figure 1 presents an overview of the MCAM method.

\section{Preparation of MCA Amplicons}

This method was adapted from an original protocol by Toyota et al. (1999). An online version is also available at http://www.mdanderson.org/departments/methylation/.

1. Digest $5 \mu \mathrm{g}$ of genomic DNA using 100 units of Smal for $16 \mathrm{~h}$ at $25^{\circ} \mathrm{C}$.

2. Add 20 units of $\mathrm{Xmal}$ and incubate the reaction for $6 \mathrm{~h}$ at $37^{\circ} \mathrm{C}$.

3. Bring the reaction volume to $500 \mu \mathrm{L}$ with $\mathrm{H}_{2} \mathrm{O}$ and add one volume of $1.5: 1$ phenol:chloroform $(\mathrm{pH}$ 9.0). Vortex the mixture for $1 \mathrm{~min}$, centrifuge for $10 \mathrm{~min}$ at $13,000 \mathrm{rpm}$, and transfer the supernatant to a $1.7-\mathrm{mL}$ microcentrifuge tube.

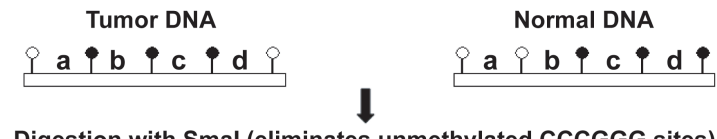

Digestion with Smal (eliminates unmethylated CCCGGG sites)

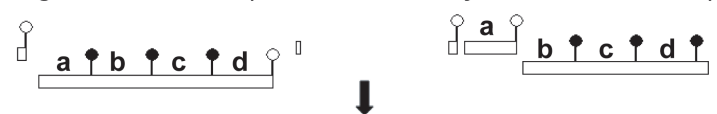

Digestion with Xmal (leaves CCGG overhangs in methylated sites)

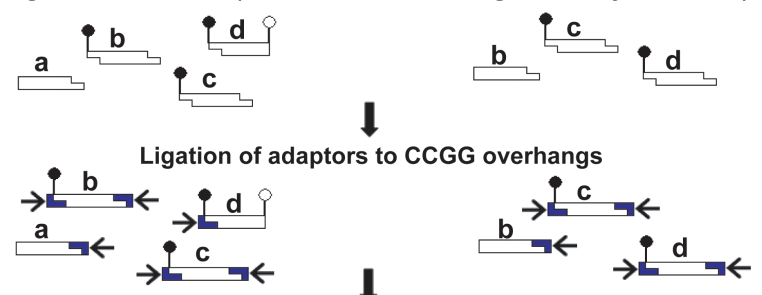

PCR amplification using adaptors (enrichment for methylated fragments)

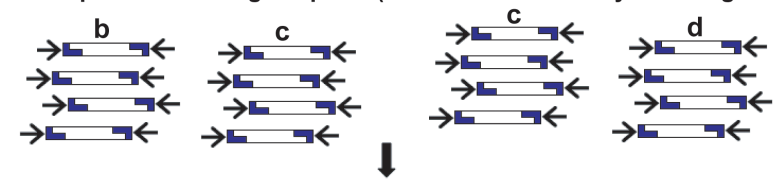

Labeling with Cy5 (tumor amplicons) or Сy3 (normal amplicons)

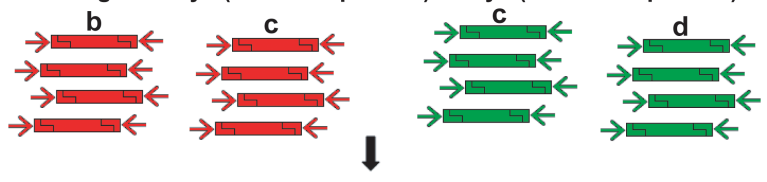

Co-hybridization, scanning and data analysis

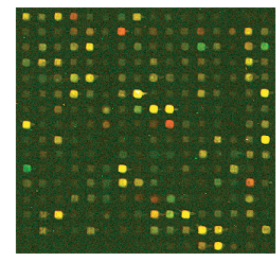

Red: $\quad \mathrm{T}>\mathrm{N}$, hypermethylation (fragment b)

Green: T < N, hypomethylation (fragment d)

Yellow: $\mathrm{T}=\mathrm{N}$, no difference in methylation (fragment c)

FIGURE 1. Schematic diagram of the MCAM method. Enrichment for methylated DNA and reduction of genome complexity is achieved by serial digestion with Smal (methylation sensitive) and Xmal (methylation sensitive) restriction enzymes, followed by ligation of adaptors and PCR amplification. The resulting amplicons, representative of the methylated fraction of tumor and normal cells, are labeled and cohybridized in a microarray platform. Image acquisition and data analysis allow identification of methylated and nonmethylated genes by comparing intensity values of Cy5 and Cy3 dyes for each pair of tumor and control samples. 
4. Precipitate the DNA by adding $1 / 10$ th volume of $3 \mathrm{M}$ sodium acetate and two volumes of $100 \%$ ethanol.

5. Incubate the sample at $-70^{\circ} \mathrm{C}$ for $1 \mathrm{~h}$, and centrifuge for $30 \mathrm{~min}$ at $13,000 \mathrm{rpm}$. Pour out the ethanol and air dry the DNA pellet.

6. Resuspend the DNA in $20 \mu \mathrm{L}$ of TE and determine the DNA concentration using a spectrophotometer.

7. Prepare the adaptor mixture as follows:

i. Dilute the RXMA (or RMCA) primers to $100 \mu \mathrm{M}$.

ii. Combine $50 \mu \mathrm{L}$ of RXMA24 with $50 \mu \mathrm{L}$ of RXMA12 (or RMCA24 and RMCA12).

8. Incubate the adaptor mix for $3 \mathrm{~min}$ at $65^{\circ} \mathrm{C}$, and cool it to room temperature over $60 \mathrm{~min}$. This mixture can be stored for up to 6 mo at $-20^{\circ} \mathrm{C}$.

9. Ligate the adaptors to the digested DNA as follows:

i. Combine the following reagents:

$\begin{array}{ll}500 \mathrm{ng} & \text { Digested DNA (Step 6) } \\ 10 \mu \mathrm{L} & \text { Adaptor mixture (Step 8) } \\ 3 \mu \mathrm{L} & \text { 10X ligase buffer } \\ 400 \text { units } & \text { T4 DNA ligase } \\ \text { to } 30 \mu \mathrm{L} & \mathrm{H}_{2} \mathrm{O}\end{array}$

ii. Incubate the ligation reaction for $16 \mathrm{~h}$ at $16^{\circ} \mathrm{C}$.

10. Prepare the MCA reactions using the following reagents:



11. Incubate the reaction for $5 \mathrm{~min}$ at $72^{\circ} \mathrm{C}$, and perform $P C R$ as follows:

\begin{tabular}{lll} 
Number of cycles & Temperature & Time \\
\hline 20 & $95^{\circ} \mathrm{C}$ & $1 \mathrm{~min}$ \\
& $72^{\circ} \mathrm{C}$ (for RXMA) or & $3 \mathrm{~min}$ \\
& $77^{\circ} \mathrm{C}$ (for RMCA) & \\
& $72^{\circ} \mathrm{C}$ (for RXMA) or & $10 \mathrm{~min}$ \\
1 & $77^{\circ} \mathrm{C}$ (for RMCA) &
\end{tabular}

12. Analyze $10 \mu \mathrm{L}$ of the PCR products on a $1.5 \%$ agarose gel to check the quality of the amplification. A relatively strong smear, ranging from $300 \mathrm{bp}$ to $2 \mathrm{~kb}$, should be visible for RXMA primers. Expect a smear ranging from $200 \mathrm{bp}$ to $1 \mathrm{~kb}$ when using RMCA primers.

\section{Labeling Amplicons and Slide Hybridization}

This hybridization protocol is optimized for the Human CpG-island 12K Array (HCGI12K) from University Health Network (www.microarrays.ca).

13. Combine PCR products of replicate samples and purify them using the QIAquick PCR Purification kit according to the manufacturer's recommendation. Elute the samples in $30 \mu \mathrm{L}$ of $1 \mathrm{X}$ TE buffer.

14. Quantify the DNA yield using a spectrophotometer. 
15. Label the PCR products.

i. Assemble each labeling reaction as follows (35- $\mu \mathrm{L}$ total volume):
$25 \mu \mathrm{L}(5 \mu \mathrm{g})$
$10 \mu \mathrm{L}(7.5 \mu \mathrm{g} / \mu \mathrm{L})$
MCA product (Step 11) in $\mathrm{H}_{2} \mathrm{O}$
Random octomer primer (8N)

ii. Denature the nucleic acids by incubating at $100^{\circ} \mathrm{C}$ for $5 \mathrm{~min}$, and then immediately transfer the tubes to ice.

iii. Add the following reagents to the nucleic acids (to a $50-\mu \mathrm{L}$ total volume):

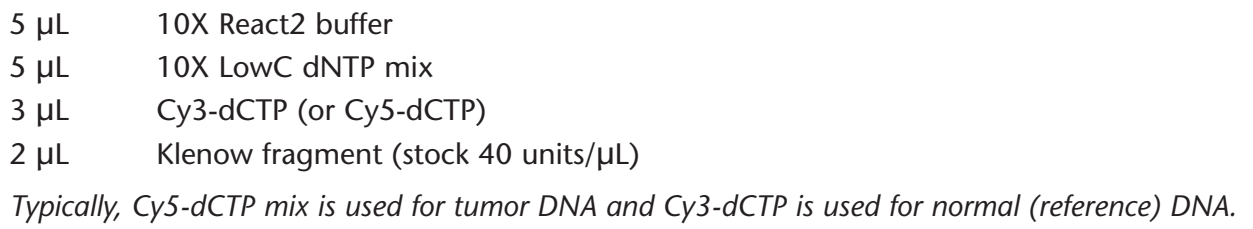

iv. Incubate the reactions for $2 \mathrm{~h}$ at $37^{\circ} \mathrm{C}$.

16. Increase the reaction volume to $100 \mu \mathrm{L}$ with $\mathrm{H}_{2} \mathrm{O}$, and purify each sample using a PCR purification kit (QIAquick) as follows:

i. Add $500 \mu \mathrm{L}$ of PBI buffer to the column in the PCR purification kit, let it stand for $5 \mathrm{~min}$, centrifuge the column for $1 \mathrm{~min}$ at 13,000 rpm, and discard the flow-through.

ii. Wash the column with $700 \mu \mathrm{L}$ of PE buffer, centrifuge for $1 \mathrm{~min}$ at 13,000 rpm, discard the flow-through, and centrifuge once again at 13,000 rpm for $1 \mathrm{~min}$.

iii. Place the column in a clean 1.7-mL microcentrifuge tube, and elute twice with $50 \mu \mathrm{L}$ of $\mathrm{H}_{2} \mathrm{O}$, waiting 2 min between centrifugations.

17. Read the samples in a spectrophotometer at the following wavelengths (use the full volume of labeled sample): Cy3= $550 \mathrm{~nm}$; Cy5= $650 \mathrm{~nm}$.

18. Calculate the concentration of incorporated dyes as follows:

Cy3 $=\mathrm{A}_{550} / 0.15=\mathrm{pmol} / \mu \mathrm{L}$ of Cy3 dye incorporated

Cy5 $=\mathrm{A}_{650} / 0.25=\mathrm{pmol} / \mu \mathrm{L}$ of Cy5 dye incorporated

Optimal amounts for hybridization are between 250 pmol (minimum) and 400 pmol (maximum) of incorporated dyes.

19. Prehybridize the slides for $45 \mathrm{~min}$ at $42^{\circ} \mathrm{C}$ in prehybridization solution for MCAM.

20. Combine equal picomole amounts of labeled tumor and normal amplicons and bring to $500 \mu \mathrm{L}$ with $\mathrm{H}_{2} \mathrm{O}$. Reduce the volume to a $15-\mu \mathrm{L}$ concentrate using a centrifugal filter unit (Microcon YM-30) as follows:

i. Centrifuge the column for $12 \mathrm{~min}$ at $14,000 \mathrm{~g}$.

ii. Invert the column in a new microcentrifuge tube and centrifuge it for $3 \mathrm{~min}$ at $5000 \mathrm{rpm}$ to collect the sample.

iii. Transfer the sample to a new microcentrifuge tube and bring the volume to $15 \mu \mathrm{L}$ with $\mathrm{H}_{2} \mathrm{O}$, if necessary.

This step typically takes 12 min at 14,000g.

21. Heat a large beaker of $\mathrm{H}_{2} \mathrm{O}$ to boiling on a hot plate.

22. Rinse microarray slides in room temperature $\mathrm{H}_{2} \mathrm{O}$.

23. Place the slides in boiling $\mathrm{H}_{2} \mathrm{O}$ for 1 min and in $4^{\circ} \mathrm{C}$ ethanol for another $1 \mathrm{~min}$.

24. Immediately centrifuge the microarrays for $6 \mathrm{~min}$ at $600 \mathrm{rpm}$ in a benchtop centrifuge.

25. Add $10 \mu \mathrm{L}$ of human Cot1 DNA (total $10 \mu \mathrm{g}$ ) and $25 \mu \mathrm{L}$ of 2 X SDS hybridization solution to the sample from Step 20. Mix gently. 
26. Denature the DNA (from Step 25) for $2 \mathrm{~min}$ at $95^{\circ} \mathrm{C}$, and hold the tubes in a $60^{\circ} \mathrm{C}$ water bath.

27. Place the microarray slides in a hybridization chamber. Add $50 \mu \mathrm{L}$ of MCAM wash solution 2 underneath each side of the slide.

28. Transfer the labeled DNA onto the array area and place a coverslip over the array.

29. Close the hybridization chamber tightly and incubate it in the dark for $16 \mathrm{~h}$ in a $60^{\circ} \mathrm{C}$ water bath. The hybridization chamber should be submerged in water, but direct contact with the bottom of the water bath should be avoided.

30. Warm two 500-mL bottles of MCAM wash solution 1 and $1500-\mathrm{mL}$ bottle of MCAM wash solution 2 to $60^{\circ} \mathrm{C}$.

31. Place the slides, with coverslips facing down, in a slide-staining dish containing MCAM wash solution 1 at $60^{\circ} \mathrm{C}$. Keep the slides at a $45^{\circ}$ angle to the bottom of the dish to allow the coverslips to detach from the microarrays.

32. Place a slide rack in a slide-staining dish filled with prewarmed MCAM wash solution 1. Transfer the slides into the dish and place it on a rocker platform set to $100 \mathrm{rpm}$ for $10 \mathrm{~min}$.

33. Transfer the slides to a new dish filled with prewarmed MCAM wash solution 2 and place it on a rocker platform set to $100 \mathrm{rpm}$ for $10 \mathrm{~min}$.

34. Rinse the slides by submerging the slide rack 10-20 times in $\mathrm{H}_{2} \mathrm{O}$.

35. Immediately centrifuge the slides for $6 \mathrm{~min}$ at $600 \mathrm{rpm}$ in a benchtop centrifuge.

36. Scan the slides.

\section{DISCUSSION}

The MCAM protocol was optimized using an array containing 12,192 CpG-island clones from the Sanger Institute (Cross et al. 1994; Heisler et al. 2005). However, this method can be applied to other array platforms, such as oligo, tiling, and custom-made arrays with larger gene representation. Our method compares favorably to other published methylation microarray protocols because it provides reproducible results with a high validation rate and demonstrated use in clinical samples for clustering cases into distinct molecular groups. In our experience, the sensitivity of methods to isolate DNA using 5-mC antibodies and methyl binding domain proteins is low, which limits their application in genome-wide studies (Weber et al. 2005; Rauch et al. 2006). The use of methylation-sensitive enzymes with frequent cutting sites, for example, Hpall/Mspl (Hatada et al. 2006), results in a high genome fraction for amplification. In such highly complex circumstances, PCR efficiency is compromised and likely favors amplification of non-CpG island DNA. In comparison, our MCAM technique simultaneously reduces complexity and increases specificity by targeting methylated CpG islands before amplification.

A limitation of our method is that the generation of MCA amplicons depends on the presence of two Smal sites in relatively close proximity (no more than 1-2 kb apart), which occurs in around $80 \%$ of the promoter CpG islands, as calculated from in silico digestion of the human genome. Also, differences in CG content make certain sequences more difficult to amplify in MCA and decrease hybridization efficiency, which may explain the presence of false-positive and false-negative data in MCAM. Despite these limitations, the low rate of false-positive data makes MCAM valuable in largescale investigations.

\section{ACKNOWLEDGMENTS}

This work was supported in part by National Institutes of Health grants P50CA100632, R01CA098006, and R33CA89837.

\section{REFERENCES}

Cross, S.H., Charlton, J.A., Nan, X., and Bird, A.P. 1994. Purification of $\mathrm{CpG}$ islands using a methylated DNA binding column. Nat. Genet. 6: 236-244.
Estécio, M.R., Yan, P.S., Ibrahim, A.E., Tellez, C.S., Shen, L., Huang, T.H., and Issa, J.P. 2007. High-throughput methylation profiling by MCA coupled to $\mathrm{CpG}$ island microarray. Genome Res. 17: 
1529-1536.

Hatada, I., Fukasawa, M., Kimura, M., Morita, S., Yamada, K., Yoshikawa, T., Yamanaka, S., Endo, C., Sakurada, A., Sato, M., et al. 2006. Genome-wide profiling of promoter methylation in human. Oncogene 25: 3059-3064.

Heisler, L.E., Torti, D., Boutros, P.C., Watson, J., Chan, C., Winegarden, N., Takahashi, M., Yau, P., Huang, T.H., Farnham, P.J., et al. 2005. CpG Island microarray probe sequences derived from a physical library are representative of $\mathrm{CpG}$ Islands annotated on the human genome. Nucleic Acids Res. 33: 2952 2961.

Rauch, T., Li, H., Wu, X., and Pfeifer, G.P. 2006. MIRA-assisted microarray analysis, a new technology for the determination of DNA methylation patterns, identifies frequent methylation of homeodomain-containing genes in lung cancer cells. Cancer Res. 66: 7939-7947.

Toyota, M., Ho, C., Ahuja, N., Jair, K.W., Li, Q., Ohe-Toyota, M., Baylin, S.B., and Issa, J.P. 1999. Identification of differentially methylated sequences in colorectal cancer by methylated $\mathrm{CpC}$ island amplification. Cancer Res. 59: 2307-2312.

Weber, M., Davies, J.J., Wittig, D., Oakeley, E.J., Haase, M., Lam, W.L., and Schubeler, D. 2005. Chromosome-wide and promoterspecific analyses identify sites of differential DNA methylation in normal and transformed human cells. Nat. Genet. 37: 853-862. 


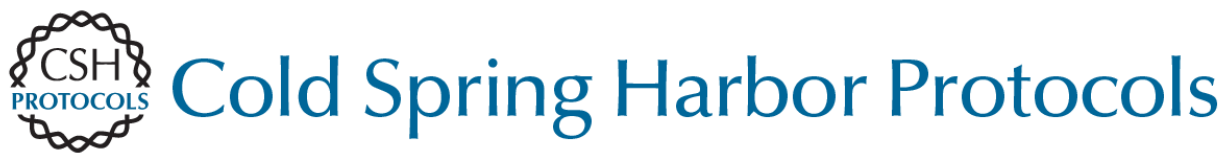

\section{Methylated CpG Island Amplification and Microarray (MCAM) for High-Throughput Analysis of DNA Methylation}

Marcos R. H. Estécio, Pearlly S. Yan, Tim H-M. Huang and Jean-Pierre J. Issa

Cold Spring Harb Protoc; doi: 10.1101/pdb.prot4974

\begin{tabular}{cc}
\hline $\begin{array}{c}\text { Email Alerting } \\
\text { Service }\end{array}$ & Receive free email alerts when new articles cite this article - click here. \\
\hline $\begin{array}{c}\text { Subject } \\
\text { Categories }\end{array}$ & Browse articles on similar topics from Cold Spring Harbor Protocols. \\
& Amplification of DNA by PCR (85 articles) \\
& Bioinformatics/Genomics, general (192 articles) \\
& DNA Modification/Epigenetics (42 articles) \\
& Fluorescence (517 articles) \\
& Fluorescence, general (341 articles) \\
& Genome Analysis (191 articles) \\
& Genomic DNA (135 articles) \\
& High-Throughput Analysis, general (155 articles) \\
& Microarrays (54 articles) \\
& Microarrays, general (55 articles) \\
& Molecular Biology, general (1293 articles) \\
& Polymerase Chain Reaction (PCR) (139 articles) \\
& Polymerase Chain Reaction (PCR), general (184 articles) \\
&
\end{tabular}

